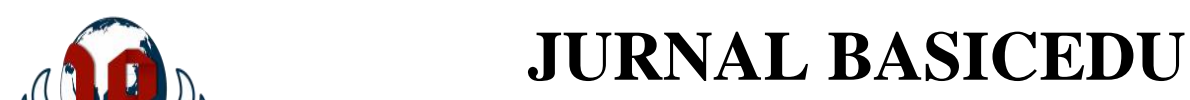

Volume 5 Nomor 3 Tahun 2021 Halaman 1577 - 1583

Research \& Learning in Elementary Education

https://jbasic.org/index.php/basicedu

\title{
Analisis Program Pelaksanaan Penguatan Pendidikan Karakter (PPK) Di Sekolah Dasar Negeri
}

\author{
Afdhal Lestari ${ }^{1 凶}$, Dea Mustika ${ }^{2}$ \\ Pendidikan Guru Sekolah Dasar (PGSD), Universitas Islam Riau, Indonesia ${ }^{1,2}$ \\ E-mail: afdhal.taluk216@gmail.com ${ }^{1}$, deamustika@edu.uir.ac.id ${ }^{2}$
}

\begin{abstract}
Abstrak
Penelitian ini bertujuan untuk mengetahui pelaksanaan Program Penguatan Pendidikan Karakter di Sekolah Dasar Negeri 004 Toar Kecamatan Gunung Toar Kabupaten Kuantan Singingi. Penelitian ini menggunakan pendekatan kualitatif deskriptif, peneliti mengeksplor pendidikan karakter terkhusus pada lima nilai utama pendidikn karakter yang di terapkan di Sekolah Dasar Negeri 004 Toar. Metode yang digunakan dalam penelitian ini adalah metode kualitatif. Analisis data penelitia meliputi Reduksi data, penyajian data, dan penarikan kesimpulan. Dalam pelaksanaan penguatan pendidikan karakter guru merancang sebuah RPP dan silabus pembelajaran. Kemudian dari pada itu dalam pelaksanaan penguatan pendidikan karakter siswa telah menunjukan karakter yang baik seperti siswa mengucapkan salam sebelum masuk kelas, memebaca doa belajar hingga mengerjakan dan menyelesaikan tugas tepat waktu. Dari hasil penelitian yang telah dilaksanakan bahwa pelsanaan penguatan pendidikan karakter (PPK) di Sekolah Dasar Negeri 004 Toar telah tercapai sesuai dengan apa yang diharapkan.
\end{abstract}

Kata Kunci: pendidikan karakter, penguatan pendidikan karakter (PPK), karakteristik siswa.

Abstract

This study aims to determine the implementation of the Character Education Strengthening Program in 004 Toar Public Elementary Schools, Gunung Toar District, Kuantan Singingi Regency. This study used a descriptive qualitative approach, the researcher explored character education, especially in the five main values of character education that were applied in the 004 Toar Public Elementary School. The method used in this research is qualitative. Research data analysis includes data reduction, data presentation, and drawing conclusions. In the implementation of strengthening character education, teachers design a lesson plan and learning syllabus. Then, in the implementation of strengthening character education, students have shown good character, such as students saying greetings before entering class, reading study prayers to doing and completing assignments on time. From the results of research that has been carried out, the implementation of strengthening character education (PPK) at 004 Toar Public Elementary School has been achieved in accordance with what was expected. Keywords: character education, strengthening character education (PPK), student characteristics.

Copyright (c) 2021 Afdhal Lestari, Dea Mustika

Corresponding author :

Email : afdhal.taluk216@gmail.com

DOI : https://doi.org/10.31004/basicedu.v5i3.912

ISSN 2580-3735 (Media Cetak)

ISSN 2580-1147 (Media Online)

Jurnal Basicedu Vol 5 No 3 Tahun 2021

p-ISSN 2580-3735 e-ISSN 2580-1147 


\section{PENDAHULUAN}

Tujuan Pendidikan Nasional Menurut (Nasional, 2003) Tentang Sistem Pendidikan Nasional dinyatakan bahwa "pendidikan nasional berfungsi mengembangkan kemampuan dan bentuk watak serta peradaban bangsa yang bermartabat dalam rangka mencerdaskan kehidupan bangsa". Bertujuan untuk berkembangnya potensi siswa agar menjadi manusia yang beriman dan bertaqwa kepada Tuhan Yang Maha Esa, berakhlak mulia, sehat, berilmu, cakap, kreatif, mandiri, dan bertanggung jawab.

Susanto dalam (Harahap, 2019) Belajar yaitu suatu aktivitas yang dilakukan seseorang dengan sengaja dalam keadaan sadar untuk memeperoleh suatu informasi, pemahaman, atau pengetahuan baru sehingga dapat terjadinya perubahan perilaku yang relatif baik dalam berpikir, merasa, maupun dalam bertindak. Sedangkan kreativitas, (Mustika \& Ain, 2020) menyatakan kreativitas merupakan kemampuan menciptakan sesuatu yang baru bermakna sosial. (Harahap, 2019) mengemukakan Mengajar adalah suatu aktivitas untuk mencoba menolong, membimbing seseorang untuk mendapatkan, mengubah atau mengembangkan skill, attitude, ideals (cita-cita), appreciations (penghargaan), dan knowledge. Dalam tahap proses belajar yang diutamakan adalah kematangan tertentu dari anak.

Dalam proses pembelajaran guru tidak hanya mentransfer ilmu pengetahuan yang dimilikinya melainkan seorang guru juga harus mampu memebentuk karakter peserta didik sesuai dengan kurikulum-13 yang menekankan terhadap pemebentukan karakter peserta didik. Pendidikan karakter merupakan salah satu kunci keberhasilan pendidikan di Indonesia, (Natalini \& Hardini, 2020). Menurut (Youpika \& Zuchdi, 2016), menegaskan bahwa pendidikan karakter merupakan proses pemberian yang diharuskan kepada peserta didik untuk menjadi manusia yang seutuhnya, yang berkarakter dalam dimensi hati, pikir, raga, rasa, dan karsa. Menurut (Kristiawan, 2016) Pendidikan karakter pada usia dini dalam keluarga bertujuan untuk pembentukan, pada usia remaja di sekolah bertujuan untuk pengembangan sedangkan pada usia dewasa di bangku perguruan tinggi bertujuan untuk pemantapan. Sejalan dengan teori di atas menurut (Mail, n.d.)Pendidikan karakter memiliki esensi dan makna yang sama dengan perilaku, moral atau pendidikan akhlak.

Maka dapat disimpulkan bahwa Pendidikan karakter menghendaki pendidikan yang bersifat humanis, jadi hal ini dimaksudkan dalam proses pembelajaran yang dilakukan di lembaga pendidikan harus mampu mengarahkan, mengembangkan dan menanamkan nilai-nilai kebaikan kepada peserta didik yang kemudian dapat diimplementasikan dalam kehidupan sehari-hari.

Sekarang, ketika masyarakat dan bangsa di landa krisis moral sistem nilai tersebut perlu di revitalisasi terutama dalam mewujudkan karakter pribadi dan karakter bangsa yang telah ada seperti tekun beribadah, jujur dalam ucapan dan tindakan, berfikir positif, dan rela berkorban. (Cahyo, 2017), Sejalan dengan pemikiran di atas dalam karakter yang baik harus terkandung tiga komponen yaitu pengetahuan moral, perasaan moral, dan tindakan moral, maka dari itu pendidikan karakter akan berjalan secara baik dan berkelanjutan sehingga siswa dapat menilai suatu tindakan melalui pengetahuannya, dapat merasakan suatu tindakan melalui perasaan moralnya, serta dapat memutuskan tindakan tersebut melalui tindakan moral yang dimiliki siswa.

Di sekolah, terutama di sekolah dasar masih terdapat sebagian siswa yang berkarakter kurang baik, dilihat dari kegiatan dilingkungan sehari-hari disekolah siswa suka berkata kotor sesame teman. Dalam kegiatan religius dan nasionalis sebagian siswa telah meunjukan sikap tersebut di lingkungan sekolah. Hal ini terlihat dari kegiatan siswa pada saat memasuki kelas, siswa mengucapkan salam dan saat memulai pembelajaran siswa memebaca doa terlebih dahulu. Selain itu Kepala Sekolah juga menegaskan bahwasanya setiap pagi senin selalu mengikuti kegiatan upacar bendera dan siswa sangat antusias dalam mengikutinya. Hanya saja masih terlihat beberapa siswa yang tidak mengikuti kegiatan dengan baik. Hal ini dikarenakan bahwa setiap siswa memilik berbagai karakteristik yang berbeda. Menurut (Putri, 2015), karakteristik perkembangan siswa sekolah dasar terbagi menjadi empat macam, yaitu senang bermain, senang bergerak, bekerja secara berkelompok, dan memeragakan sesuatu secara langsung. 
Oleh karena itu, merupakan langkah yang positif ketika pemerintah atau Mendiknas merevitalisasi pendidikan karakter dalam seluruh jenis dan jenjang pendidikan. Melalui pendidikan karakter, kita berharap bangsa ini menjadi bangsa yang bermartabat, dan masyarakatnya memiliki nilai tambah, dan nilai jual yang bisa ditawarkan kepada orang lain dan bangsa lain di dunia, sehingga kita bisa bersaing, bersanding bahkan bertanding dengan bangsa-bangsa lain dalam percaturan global.

Peraturan Presiden No. 87 tahun 2017 tentang PPK merupakan pembuka ruang untuk sinergi antara antara sekolah dan komunitas yang bergerak dalam pengembangan nilai-nilai luhur. Menurut (Tim Penyusun, 2016) pelaksanaan gerakan PPK disesuaikan dengan kurikulum pada satuan pendidikan masing-masing dan dapat dilakukan melalui tiga cara, yaitu: (1) Mengintegrasikan pada mata pelajaran yang ada di dalam struktur kurikulum dan mata pelajaran Muatan Lokal (Mulok) melalui kegiatan intrakurikuler dan kokurikuler. Sebagai kegiatan intrakurikuler dan kokurikuler, setiap guru menyusun dokumen perencanaan pembelajaran berupa Silabus dan Rencana Pelaksanaan Pembelajaran (RPP) sesuai mata pelajarannya masing-masing. Nilai-nilai utama PPK diintegrasikan ke dalam mata pelajaran sesuai topik utama nilai PPK yang akan dikembangkan/dikuatkan pada sesi pembelajaran tersebut dan sesuai dengan karakteristik mata pelajaran masing-masing.

(2) Mengimplementasikan PPK melalui kegiatan ekstrakurikuler yang ditetapkan oleh satuan pendidikan. Pada kegiatan ekstrakurikuler, satuan pendidikan melakukan penguatan kembali nilai-nilai karakter melalui berbagai kegiatan. Kegiatan ekskul dapat dilakukan melalui kolaborasi dengan masyarakat dan pihak lain/lembaga yang relevan, seperti PMI, Dinas Kelautan dan Perikanan, Dinas Perdagangan, museum, rumah budaya, dan lainlain, sesuai dengan kebutuhan dan kreativitas satuan pendidikan. (3) Kegiatan pembiasaan melalui budaya sekolah dibentuk dalam proses kegiatan rutin, spontan, pengkondisian, dan keteladanan warga sekolah. Kegiatan-kegiatan dilakukan di luar jam pembelajaran untuk memperkuat pembentukan karakter sesuai dengan situasi, kondisi, ketersediaan sarana dan prasarana di setiap satuan pendidikan. (Subadar, 2017) Pondasi awal tujuan penerapan PPK adalah membangun generasi ideal yang menguasai keterampilan abad 21 .

Tujuan penelitian dari penelitian ini adalah untuk mengetahui pelaksanaan Program Penguatan Pendidikan Karakter di Sekolah Dasar Negeri 004 Toar Kecamatan Gunung Toar Kabupaten Kuantan Singingi.

\section{METODE}

Metode yang digunakan pada penelitian ini adalah kualitati. Pendekatan kualitatif merupakan penelitian yang digunakan untuk meneliti pada kondisi obyek yang alami, dimana peneliti merupakan sebagai instrumen kunci, teknik pengumpulan data dilakukan secara triangulasi , analisis data bersifat induktif, dan hasil lebih menekankan makna dari pada generalisasi , (Natalini \& Hardini, 2020)Dengan pendekatan kualitatif deskriptif. Peneliti deskriptif yaitu ditunjukkan untuk mendekripsikan suatu keadaan atau fenomena-fenomena apa adanya, Sukmadinata (Atika et al., 2019). Maka dapat disimpulkan bahwa penelitian kualitatif deskriptif merupakan penelitian yang berusaha dalam menemukan fakta atau fenomena dari pemahaman orang-orang yang terlibat dalam peneliti.

Dalam penelitian ini peneliti mengumpulkan data tanpa melakukan intervensi terhadapp subjek penelitian. Peneliti juga tidak melakukan manipulasi data atau memberikan pengaruh baik terhadap narasumber maupun aktivitas yang terjadi dilapangan. Maksudnya peneliti melakukan penelitian dalam setting alami karena data yang diperoleh adalah apa yang ada di lapangan. Dalam penelitian ini, data yang dikumpulkan yaitu data terkait dari lima nilai utama pendidikan karakter.

Selanjutnya inkuiri nturalistik menggunakan purposive sampling, yaitu menggunakan sampel tertentu yang ditunjuk untuk menjawab atau sebagai sumber data penelitian; data dalam penelitian inkuiri naturalistik dianali sis secara induktif, yaitu analisis peneliti dibangun dari fakta-fakta sebagai hal-hal khusus menjadi hal umum. Dalam penlitian ini peneliti tidak membuat desain baku dalam penelitian ini, tetapi peneliti 
memungkinkan akan memunculkan desain penelitian karena banyak hal-hal yang tidak terduga temui pada saat penelitian.

Penelitian ini dilaksanakan di Sekolah Dasar Negeri 004 Toar Kecamatan Gunung Toar Kabupaten Kuantan Singingi. Alasan memilih sekolah ini yaitu pada dasarnya sekolah sudah berdiri sejak lama dan sudah menggunakan kurikulum K13 serta memiliki guru-guru yang lebih senior. Sumber data dalam melakukan penelitian ini yaitu dari subjek penelitian. Data yang akan diperoleh dalam penelitian ini bersumber dari data primer dan data sekunder, Bungin (dalam Helminsyah, dkk,2019: 241). Adapun subjek data dalam penelitian ini yaitu kepala sekolah, guru-guru, dan siswa, untuk memperoleh informasi mengenai pelaksanaan lima nilai utama pendidikan karakter. Proses penelitian meliputi: (1) survey lokasi penelitian. (2) penentuan topik masalah penelitian; (3) penyusunan instrumen; (4) pengambilan data dilapangan dilakukan selama 2 minggu berturut turut; (4) analisis data (coding); (5) membuat pembahasan dan kesimpulan. Teknik pengumpulan data dalam penelitian ini adalah; (1) wawancara; (2) observasi; dan (3) dokumentasi. (Mail, n.d.)dalam penelitian, setiap temuan penelitian harus dicek keabsahan nya agar hasil penelitian dapat di pertanggung jawabkan kebenarannya dan dapat dibuktikan keabsahannya. Untuk memeriksa keabsahan data peneliti menngunakan trianggulasi sumber, trianggulasi metode dan trianggulasi waktu. Moleong (dalam Hadi, 2017: 90) Trianggulasi merupakan teknik pemeriksaan keabsahan data yang didasari pola pikir fenomenologis yang bersifat multi perspektif, maksudnya adalah menarik kesimpulan dengan memakai beberapa cara pandang.

\section{HASIL DAN PEMBAHASAN}

Penelitian dilakukan di Sekolah Dasar Negeri 004 Toar Kecamatan Gunung Toar kabupaten Kuantan Singingi, pada tanggal 8-16 Maret 2021 tentang pelaksanaan penguatan pendidikan karakter (PPK). (Atika et al., 2019) menyatakan bahwa Salah satu upaya pemerintah tentang pendidikan karakter adalah Penguatan Pendidikan Karakter (PPK) yang terintegrasi dalam Gerakan Nasional Revolusi Mental, yaitu perubahan cara berpikir, bersikap dan bertindak menjadi lebih baik. Penelitian ini dilakukan dengan berpanduan pada 5 nilai utama pendidikan karakter yaitu, religius, nasionalisme, gotong royong, mandiri dan integritas.

Lima nilai utama diatas selanjutnya peneliti mengembangkan menjadi sub-indikator yaitu mengucapkan salam sebelum memasuki kelas, membaca doa sebelum memulai pembelajaran, membaca al-Qura'an atau membaca ayat pendek, mengikuti aturan sekolah, menghormati keberagaman suku, budaya dan agama, menunjukan sikap tolong menolong, menunjukan sikap bekerja sama, menunjukan sikap bekerja keras, berani mengambil keputusan, jujur dalam mengucapkan sesuatu dan mengerjakan serta menyelesaikan tugas tepat waktu.

Data yang peneliti dapatkan dari hasil observasi, dokumentasi dan wawancara bersama guru, kepala sekolah, dan siswa, seluruh siswa di Sekolah Dasar Negeri 004 Toar telah menerapakn lima nilai utama pendidikan karakter di sekolah, ini terlihat dari nilai religius seluruh siswa SD Negeri 004 Toar selalu mengucapkan salam sebelum masuk kelas setelah itu untuk mengawali pembelajaran guru membimbing siswa untuk membaca doa belajar sesuai dengan RPP dan silabus yang telah dibuat, yang dipimpin oleh ketua kelas selanjutnya siswa membaca ayat pendek untuk mengingat kembali hapalan-hapalan ayat pendek yang telah dipelajari. 


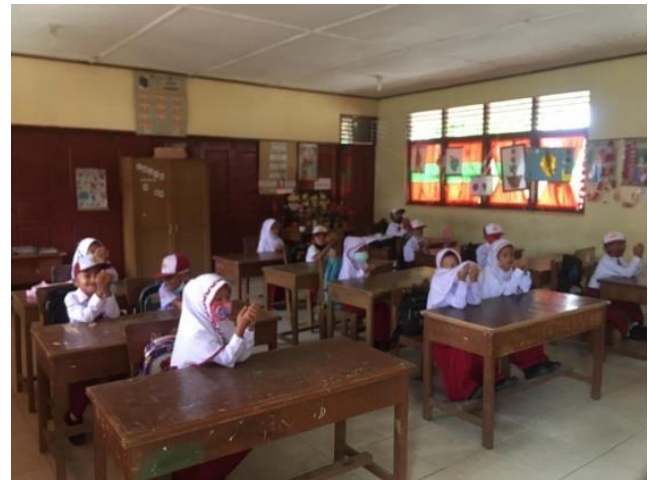

\section{Gambar 1. Siswa membaca doa belajar}

Dari nilai nasionalisme peraturan di sekolah yang telah ditetapkan baik itu peraturan di kelas maupun dilingkungan sekolah tidak ada siswa yang melanggarnya, siswa selalu berpakaian lengkap dan rapi serta tambahan untuk memakai masker saat pendemi, jika ada siswa yang melanggar akan dikenakan sanksi sesuai dengan apa yang diperbuat, dalam lingkungan sekolah seluruh siswa saling menghomati keberagaman suku, budaya dan agama hal ini sesusai dengan peraturan yang ada dan di terapkan secara langsung maupun didalam proses belajar mengajar sesuai dengan panduan RPP dan silabus yang telah dibuat.

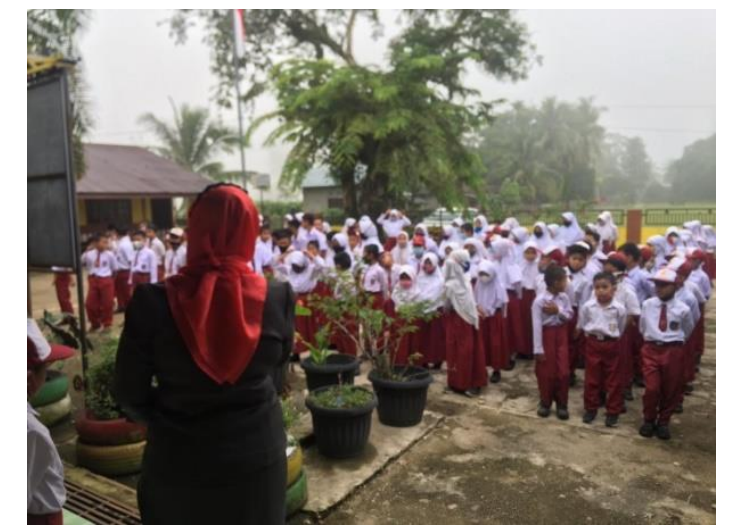

\section{Gambar 2. Berbaris mengecek kerapian siswa}

Dari nilai gotong royong dalam lingkungan sekolah maupun dalam proses belajar siswa selalu membantu satu sama lain dilihat dari menolong siswa yang butuh alat tulis, mengerjakan piket maupun mengikuti bakti sosial disekolah. Dari nilai mandiri dalam mencapai hasil yang bagus seluruh siswa di sekolah dasar negeri 004 toar selalu bekerja keras untuk mencapainya terutama dalam mencapai hasil belajar sehingga nantinya menjadi juara kelas, dengan keberanian sendiri siswa selalu mengambil keputusan sesuai dengan pemahamnnya tanpa bantuan orang lain, tapi masih ada terdapat sebagian kecil siswa yang belum berani untuk mengambil keputusan sendiri, dan dari nilai integritas, kejujuran merupakan hal utama yang diterapkan di SD Negeri 004 Toar hal ini selalu di sampaikan oleh kepala sekolah mapun guru baik dilingkungan sekolah maupun saat proses belajar mengajar, siswa disekolah salalu berbuat jujur baik itu sesama teman maupun kepada guru, saat mengerjakan tugas siswa selalu menyelesaikannya tepat waktu tapi ada terdapat sebagian kecil siswa yang tidak menyelesaikan tugas tepat waktu. Lickona (dalam Agung, 2017: 108) mengemukakan, pendidikan karakter merupakan usaha yang disengaja untuk membantu seseorang sehingga dapat memahami, memperhatikan, dan melakukan nilai-nilai etika yang inti.

Berdasarkan pengamatan peneliti, guru dalam memberikan arahan kepada peserta didik dan juga sebagai model pendidikan karakter, guru sudah berperan secara maksimal, untuk mencapai karakter yang baik, peran guru dalam meningkatkan nilai-nilai karakter dengan memberi contoh yang baik dan nantinya akan dicontoh oleh peserta didik. Peneliti juga mengamati upaya kepala sekolah dan guru lakukan sebagai model pendidikan 
1582 Analisis Program Pelaksanaan Penguatan Pendidikan Karakter (PPK) Di Sekolah Dasar Negeri Afdhal Lestari, Dea Mustika

DOI: https://doi.org/10.31004/basicedu.v5i3.912

karakter. Peran guru dalam hal ini sebagai upaya untuk melaksanakan program penguatan pendidikan karakter (PPK) sudah sesuai dengan apa yang diharapkan dan juga telah diteladani oleh siswa di Sekolah Dasar Negeri 004 Toar Kecamatan Gunung Toar Kabupaten Kuantan Singingi.

\section{KESIMPULAN}

Sekolah dasar diakui memiliki peran penting dalam pengembangan fondasi karakter individu. Oleh karena itu seluruh aktivitas pendidikannya harus mampu memfasilitas penanaman dan pengembangan terhadap nilai peserta didik agar berbudi pekerti yang luhur. Pendidikan karakter sangat penting diterapkan di sekolah dasar, apalagi pada saat sekarang perkembangan teknologi globalisi semakin pesat yang nantiknya seluruh elemen masyarakat baik masih kecil maupun sudah besar mampu menerima dengan baik. Pada dasarnya sekolah tetap mengaitkan pendidikan karakter terhadap visi misi sekolah. Demi tercapainya siswa siswi yang berakhlak mulia. Selain itu siswa harus mencapai lima nilai karakter utama yang nantiknya akan diterapkan dilingkungan sekolah maupun lingkunga masyarakat sesuai dengan anjuran pemerintah dan seusai dengan kurikulum yang digunakan di sekolah yakni K13.

\section{UCAPAN TERIMA KASIH}

Saya sebagai peneliti mengucapkan terima kasih kepada Sekolah Dasar Negeri 004 Toar Kecamatan Gunung Toar kabupaten Kuantan Singingi karena telah memberikan izin dan meluangkan waktu kepada saya untuk melaksanakan penelitian ini. Dan saya mengucapkan terima kasih kepada bapak ibu dosen yang membimbing saya dalam melaksanakan penelitian ini. Saya tidak dapat membalas kebaikan bapak dan ibu, hanya Allah SWT yang dapat membalas kebaikan bapak dan ibu semuanya. Serta saya juga sangat berterimakasih kepada kedua orang tua, keluarga besar saya yang selalu memberi semangat dan dukungan untuk menyelesaikan tugas akhir ini.

\section{DAFTAR PUSTAKA}

Atika, N. T., Wakhuyudin, H., \& Fajriyah, K. (2019). Pelaksanaan Penguatan Pendidikan Karakter Membentuk Karakter Cinta Tanah Air. Mimbar Ilmu, 24(1), 105-113.

Cahyo, E. D. (2017). Pendidikan karakter guna menanggulangi dekadensi moral yang terjadi pada siswa sekolah dasar. EduHumaniora| Jurnal Pendidikan Dasar Kampus Cibiru, 9(1), 16-26.

Harahap, E. O. (2019). Hubungan Antara Kemampuan Memahami Isi Bacaan Dengan Hasil Belajar Siswa Pada Mata Pelajaran Bahasa Indonesia Di Kelas IV SD Negeri 067690 Medan Johor Tahun Pelajaran 2017/2018. Komunikologi: Jurnal Pengembangan Ilmu Komunikasi Dan Sosial, 3(1), 53-58.

Kristiawan, M. (2016). Telaah Revolusi Mental dan Pendidikan Karakter dalam Pembentukkan Sumber Daya Manusia Indonesia Yang Pandai dan Berakhlak Mulia. Ta'dib, 18(1), 13-25.

Mail, Z. H. R. (n.d.). Analisis Implementasi Pendidikan Karakter Di Sekolah Dasar Negeri 115 Pekanbaru. School Education Journal Pgsd Fip Unimed, 10(1), 8-16.

Mustika, D., \& Ain, S. Q. (2020). Peningkatan Kreativitas Mahasiswa Menggunakan Model Project Based Learning dalam Pembuatan Media IPA Berbentuk Pop Up Book. Jurnal Basicedu, 4(4), 1167-1175.

Nasional, D. P. (2003). Undang-undang republik Indonesia nomor 20 tahun 2003 tentang sistem pendidikan nasional. Language, $188,22 \mathrm{~cm}$.

Natalini, B., \& Hardini, A. T. A. (2020). Implementasi Program Pendidikan Karakter Di SD Kanisius Gendongan Salatiga. JRPD (Jurnal Riset Pendidikan Dasar), 3(1), 77-86.

Putri, D. K. (2015). Keefektifan Penggunaan Model Mind Mapping Dalam Pembelajaran Ips Pada Siswa Kelas Iii Sdn 1 Kramat Kabupaten Purbalingga. Universitas Negeri Semarang.

Subadar, S. (2017). Penguatan Pendidikan Karakter (PPK) Berbasis Higher Order Thinking Skills (HOTS). 
1583 Analisis Program Pelaksanaan Penguatan Pendidikan Karakter (PPK) Di Sekolah Dasar Negeri Afdhal Lestari, Dea Mustika

DOI: https://doi.org/10.31004/basicedu.v5i3.912

PEDAGOGIK: Jurnal Pendidikan, 4(1).

Tim Penyusun, P. P. K. (2016). Pedoman Penilaian Penguatan Pendidikan Karakter Tingkat Sekolah Dasar dan Sekolah Menengah Pertama. Jakarta: Kementerian Pendidikan Dan Kebudayaan Republik Indonesia.

Youpika, F., \& Zuchdi, D. (2016). Nilai pendidikan karakter cerita rakyat suku Pasemah Bengkulu dan relevansinya sebagai materi pembelajaran sastra. Jurnal Pendidikan Karakter, 1. 